\title{
Migrations As a Challenge for Dispositional Groups in Polish and European Comparative Perspectives
}

\author{
Aleksandra SKRABACZ \\ Pomeranian University, Slupsk, Arciszewskiego, Poland \\ aleksandraskrabacz@interia.pl
}

Received date: 30 September 2020; Accepted date: 3 February 2021; Published date: 2 June 2021

Academic Editor: Wojciech Szczepan Staszewski

Copyright (C) 2021. Aleksandra SKRABACZ. Distributed under Creative Commons Attribution 4.0

International CC-BY 4.0

\begin{abstract}
The article provides a discourse on the essence of the functioning of dispositional groups in the perspective of contemporary migration processes and new procedures that have been implemented to make public decisions in the official social forum. It contributes two new perspectives to the development of social sciences. The first perspective relates to the migration movements characteristic of the second decade of the 21st century and on a number of challenges for Europe and Poland. The second perspective analyses the preparation of services in response to new threats in the area of security. In the implementation of the adopted research assumptions, a certain methodological eclecticism was employed, allowing the combination of methods from various scientific disciplines, which is a characteristic of the methodology of security research, thus ensuring cognitive and pragmatic efficiency. Using theoretical methods, including the analysis and synthesis of knowledge available in compact and continuous sources (traditional and electronic), the essence of the functioning of dispositional groups was discussed, in a typological way, characterizing the specificity of operation. Using the comparative method, the problems encountered by the dispositional groups of European countries were indicated. Using exemplification, specific examples of threats to the security of the host society and for the migrants themselves are discussed. The article primarily uses the results of qualitative research by Polish and foreign scientists on disposable groups, while quantitative methods were used to analyze migration problems.
\end{abstract}

Keywords: Dispositional Groups, Migrations, Threats, European Union, Poland

Cite this Article as: Aleksandra SKRABACZ (2021)," Migrations As a Challenge for Dispositional Groups in Polish and European Comparative Perspectives ", Journal of Eastern Europe Research in Business and Economics Vol. 2021 (2021), Article ID 290391, DOI: 10.5171/2021.290391 


\section{Introduction}

Migration is a process that has always been observed around the world. Throughout history, populations have moved for a wide range of reasons, either voluntarily or forced by external circumstances. Migration flows that follow the events across the world take on various intensities, and their direction is determined by the current political, economic and social trends. From a European perspective, the last significant wave of migration in 2011, initiated by the Arab Spring, had a significant impact on the population of Europe. Data from the International Organization for Migration, indicates that over 390,000 people moved to the European continent in 2016. The data also evidences that in 2017, there were over 180,000 illegal immigrants, and by November 2018, almost 130,000 had arrived, of which, over 106,000 were by sea with the remainder by land (IOM, 2019).

In 2019, 714,200 applications for international protection were submitted in the EU (plus Norway and Switzerland), which signifies an increase of $13 \%$ compared to 2018. In addition, the data shows that protection was granted to almost 295,800 asylum seekers, a decrease from 333,400 in 2018 and 533,000 in 2017. Almost one third (27\%) of the asylum seekers were from Syria, with the three highest groups including Afghanistan $(14 \%)$ and Venezuela (13\%). The number of migrants from Venezuela increased by almost $40 \%$ in 2019 compared to 2018. Of the 78,600 Syrians granted international protection in the EU, almost $71 \%$ received it in Germany (European Parliament, 2020).

Overall, more than 82 million international migrants resided in Europe in 2019, an increase of almost $10 \%$ from 2015 , when 75 million international migrants lived in the region. Between 2015 and 2019, the non-European immigrant population increased from just over 35 million to approximately 38 million (World Migration Report 2020).
Migrants arriving in Europe brought with them psychological issues related to traumatic events, and this fueled their high expectations of the gains they hoped to have with regard to aspects such as work, housing, and living conditions, as well as education, social and cultural gains. The reality they across the European countries, often fell short of the expectations, and, on occasion, would lead to tensions and frustration. In many regions, migrants were not welcomed or they even faced acts of hostility. Antagonisms occurring between the host community and new arrivals have become a significant challenge for many local services. Often, local services are scarce and, under resourced, so the additional demand has caused tensions between migrants and the native population. Dispositional groups, therefore face a dilemma regarding which actions will both ensure the safety of the native communities, and simultaneously assist immigrants in adapting to new living conditions, whilst respecting their inalienable and inherent human rights.

Hence, the main research inquiries focus on the following thesis: migration, understood both in the context of emigration and immigration, has a significant impact on the functioning of dispositional groups. This implies the needs and expectations visible in two areas: firstly, inside the milieu of uniformed services, which may be caused by language, cultural or social barriers as well as staff shortages, and even a direct threat to the life and health of officers. Secondly, the area formulated by the authorities and society in relation to the efficiency and effectiveness of these groups, even in terms of ensuring the safety of local communities, as well as breaking the law and violating social norms by immigrants.

The results of the analysis undertaken in the article are of a utilitarian nature both in the present and perspective dimensions. The experiences of European countries may provide a useful direction for other countries of Central and Eastern Europe enabling them to prepare for any future large scale migration. 


\section{The specificity of dispositional groups}

The term "dispositional group" has appeared not only in the language of sociology, but also in the terminology of security sciences, and is the object and subject of research of various scientific environments, including sociological, political, pedagogical and security issues. It is a very extensive area of research, just like the entire milieu of uniformed formations. Therefore, although these groups are discussed and interpreted differently in literature, they share a common goal of action, which is a direct, immediate protection and defense of society against all threats, regardless of whether they are military, paramilitary, civil or volunteer groups (Bogdalski et al., 2014).

When it comes to the concept of a dispositional group, it is worth considering Maciejewski's definition (2012), which is considered to be one of the precursors of research on dispositional groups. In the author's opinion, dispositional groups are "such social structures, whose availability we can speak of in a narrow sense due to their specialized and specific nature of activities in a relatively limited scope". What does disposition mean? Well, it is about the general and specific ability of the above mentioned groups to carry out team activities in a planned and fixed manner, in accordance with the tasks assigned to a given dispositional group.

Morawski (2005) looks at dispositional groups from a different perspective. Morawski believes that this is "a special kind of group with a state-shaped structure and hierarchy, in which smaller groups make up larger ones. The groups are entirely subordinated to the administrator". This view corresponds with Zagórski's definition (2000), who, defining the purpose of the groups' activity, states that "they are intended to stabilize the system of state power and protect it against internal as well as external threats and catastrophes of various natures". It can, therefore, be generalized that the dispositional group is a special social group, characterized by specific readiness to act, the so-called availability, operating in a planned and organized manner, and having a specific structure within which its members function in a hierarchical manner, and the purpose of its activities are areas related to securing the life and health of citizens, stable functioning of the state and protection of property and the environment.

Why is there a need to separate dispositional groups from many other social groups? It arises from two basic issues; the first one is related to the specific characteristics of the members of these groups, who are usually distinguished by dedication and commitment to the implementation of tasks in difficult situations that require courage, dedication and availability. Due to the difficult operating conditions, they require specific procedures, staff selection and preparation methods (Bogdalski et al., 2014). Therefore, it is worth emphasizing the requirement of high professional qualifications and the ability to act efficiently in various situations and conditions of members of dispositional groups, but it is also important to add here high social competences, i.e. specific psychophysical features and social skills, focusing on human behaviors, attitudes, way of living, teamwork, acting under time pressure, motivation or communication and interpersonal skills. It is only a combination of these so-called hard and soft competences that determines the professional and social value of dispositional groups.

The second issue, according to M. BsoulKopowska (2017) results from "functioning in larger structures, such as military or paramilitary organizational units, in which there is a specific attitude to work referred to as "service", and a militarized organization and command-based order. In this kind of units, e.g. divisions or police garrisons, there are teams of selected and specially trained people, capable of taking rapid actions arising from special circumstances, such as the need for immediate intervention in connection with a terrorist attack, resulting riots and 
similar events. The very word "service" carries a certain emotional load that significantly distinguishes the nature of the activities performed. The Polish dictionary defines service as "work for a community, done with dedication". This community should be understood both in the context of individual and social groups in relation to which there is a legal obligation to provide assistance, regardless of the circumstances in which it is provided.

Hence, Zalewski (2014), while listing such features of dispositional groups as hierarchy and formal subordination to the state and its authorities, draws attention to another attribute of dispositional groups, namely the disposition of administrative resources for citizens. However, as he explains: "In this context, it is worth paying attention to the differences in position and function (resulting from the scope of tasks and powers) in terms of a decision-maker, as well as the diversity of social roles of group members (citizens assign a different role to soldiers, another to policemen or firemen; completely different from the role of intelligence and counterintelligence officers, - mainly because it is poweroriented, not citizen-oriented)". This thesis is confirmed by surveys of the ranking of professions enjoying the greatest social recognition, in which for many years among the uniformed services, the first place is occupied by a firefighter $(87 \%$ of declarations of high respect), followed by a policeman ( $68 \%$ of positive grades) and a soldier (59\% of good grades) (COBOS 2013). Therefore, in the opinion of the society, these professions are the epitome of the idea of commitment and unconditional service of the community along with personal risk of a direct threat to life and health. On the one hand, they enjoy high social recognition, but on the other hand, people expect an impeccable ethical and moral attitude along with respect for legal and social norms from them. There is another significant difficulty connected with this idea. In a democratic state in which the people are the sovereign - or more specifically a civil society - there may be a level of conflict between the expectations of civil liberties and freedom, and satisfying the requirements for security. In Zalewski's opinion (2014), "In a democratic state, we are talking about civil society as an object of protection, but also the basic determinant of the political community of free people, i.e. those who have as wide a range of personal, political as well as economic, social and, nowadays, cultural rights as possible and the right to information. This community can function only in conditions of relative security, which is generally the task of these dispositional groups. [...]. Therefore, the key issue is to recognize the dynamics of mutual relations between hierarchically organized security structures and civil society, which today takes the form of information (network). This society quite freely uses more and more information resources, largely outside the control of national authorities. Ensuring security under these conditions is a major challenge for national governments. States are trying to "keep up" with the expanding sphere of people's activity, embracing it with everwidening control", and this is often perceived as overt and unwelcome state control. Considering, the problem of international migration against such a background of functioning of dispositional groups in a democratic country, and such as the European Union, it is clear to recognize the complexity of the situation.

Considering the problem from the perspective of the availability of dispositional groups, it is clear to see the complexity of the dual role they are required to play. Not only do they have to protect and support the native population, but simultaneously and within the same arena, they are required to integrate a migrant group, often with different cultural beliefs and aspirations. This challenge is further compounded by language difficulties, the possible presence of psychological trauma, and in some extreme cases, conflict with the host community. Therefore, as a result of migration, completely new security requirements are often created, especially in the cultural, economic, public, social, health and universal dimensions.

Maciejewski (2012) categorized the dispositional groups into military, 
paramilitary, civil and voluntary groups. The military includes those that operate in the military social system, whose main purpose is to defend the sovereignty of the state. The second group - paramilitary, includes all those formations that are organized in a military pattern, including the Police, State Fire Service, Border Guard, the State Protection Service, the Foreign Intelligence Agency, and the Internal Security Agency. Civilian dispositional groups are represented by institutions functioning both in the structures of government and self-government administration as well as private enterprises. Although they have one goal in common, which is ensuring broadly understood security; they can discharge through public and private funds. Among the voluntary dispositional groups, i.e. those whose members generally operate on a voluntary basis, those worthy of mention include Mountain Volunteer Rescue Service, Water Volunteer Rescue Service and many other organizational and legal types, including volunteer fire brigades. Due to the subject of scientific research discussed in this article, which are migration processes, the research attention will focus primarily on paramilitary dispositional groups, taking as a starting point, the thesis that members of these formations are primarily dealing with migration movements taking place in Europe and they should effectively deal with the migration challenges posed by the second decade of the 21st century.

Another significant factor relating to dispositional groups is that democratic societies expect members of these groups to have special predispositions not only psychophysical, but also ethical and moral. Dispositional groups have the opportunity to act efficiently only when they receive a level of trust from the society they serve, confirming the need for their existence through the prism of social acceptance. For this to happen, communities and the media, especially at the local level, are closely monitoring the actions of members of these formations, loudly condemning all their violations of legal and customary norms.
An interesting study of selected social patterns of individual dispositional groups was presented by Maciejewski (2012), pointing to the specific physical, psychosocial, cultural, moral and professional characteristics of members of the individual uniformed formations. Focusing on soft competences, it is worth paying attention to the special predispositions of policemen whose "moral attitude towards citizens is manifested in respect for human dignity, courage and self-sacrifice, observance and protection of human rights, kindness, courtesy, tactfulness, impartiality, responsibility, high personal culture, discretion, integrity, respect for others or caring for the image of the police". Similar expectations are formulated in relation to Border Guard officers, except that in this area special emphasis is placed on respecting the dignity of persons subjected to inspections, and in particular personal searches, in which officers get in contact with people with a different worldview or cultural custom.

Slightly different requirements are imposed on members of the fire brigade and paramedics. For both professions, full professionalism and readiness to help victims in all conditions, even those in which their own life and health are at risk, is required, as is often the case with rescue operations conducted by firefighters. The work of paramedics looks a little different, who, - in addition to the above-mentioned features, - should also be characterized by resistance to stress, the ability to make quick decisions, often under time pressure and anticipating the effects of these decisions. The factor regarding what environment paramedics work in is not without significance. They can find themselves being required to assist citizens under the influence of alcohol or intoxicants, aggressive both physically and verbally, as well as possessing weapons or other dangerous tools. Hence, there are situations in which paramedics, going to specific pathogenic environments, ask for support from the police, in order to protect their own lives and health. Therefore, it is necessary to properly prepare the members of the dispositional groups to 
work in, often challenging environment, and not only in the physical sense, but also in the social, cultural or moral one.

\section{Migration challenges of the 21st century}

The first decades of the 21st century brought great migration movements to Europe, which had a significant impact in many ways, affecting both the host countries and those from which the population flows away en masse. In Matis' opinion (2016), such a large influx of foreigners is one of the main problems of European countries, and mass migration has acquired the features of an epic crisis. It cannot be equated with escape, because migrants leave their land not because of fear for their own lives, but for purely economic reasons. Mass illegal migration prevents the process of cultural assimilation with the host society because countries do not have time to thoroughly check the details of arriving persons and regulate their inflow. According to this author, European countries are divided into optimists and pessimists when it comes to the view on multi-culturalism of modern Europe. Optimists say migration will help build a "new European nation" that will be devoid of nationalism. In turn, pessimists believe that multi-culturalism, in the clash with radical Islam, poses significant risks for further integration of the European Union.

Both positions hold elements of truth and it is indisputable that large scale migration into Europe will present many challenges, especially in political, social, economic, demographic and cultural terms, as Janicka (2018) indicates when analyzing the effects of migration processes. Looking from the perspective of EU countries, it is worth adding one more area that is of fundamental importance for the peaceful coexistence of various social groups, namely ensuring security that must be faced by societies and national and EU governments.

When it comes to shaping security, political scientists point out that: "Security issues have traditionally been considered in the light of national security. As a result, relatively few researchers have attempted to theoretically capture the complexity of a phenomenon that can be described as a tangle of links between migration and security. And yet, the issue of security has a much broader scope and also includes population security. Lack of security is frequently experienced by international migrants. In fact, it is their insecurity that should become the most important problem in security research" (Castles and Miller, 2011).

Castles and Miller (2011) emphasize that "before September 11, 2001, researchers dealing with international relations and international security paid very little attention to international migration. And vice versa - researchers dealing with international migration have rarely analyzed its implications for security or understanding international relations or the world politics". This situation has now changed radically. Migrants have become a significant challenge for EU countries, contrasting significantly with migration 50 years, which was often regarded as both economically and socially positive. Uncontrolled migration, however, has quickly become one of the biggest problems facing European countries, especially those centered around the Mediterranean Sea.

The specificity of the current migration crisis results from the demographic aspect, particularly evident in the large disproportion of young men to women, and the difficulties in integrating immigrants into the host society, especially in the social and cultural area (Bazan, 2017). The basic push and pull factors include, first and foremost, financial aspects resulting from high rates of social benefits granted to immigrants and other aspects of social care provided to large families. For example, in Germany, in 2015, the immigrant, in addition to accommodation, meals and clothes, received money for his own expenses in the amount of 352 EUR per month, of which 143 EUR in cash. In the case of a family, the sum of all benefits could be up to EUR 1,000 per month (TVN, 2018). 
However, material benefits are not the only reason for the popularity of Western European countries among immigrants who, when choosing the direction of migration, consider factors such as rule of law, lack of corruption, good career prospects, education for children and a sense of security, and, one very important factor - the presence of people of the same origin who have already emigrated and are a point of reference in the first months of their stay abroad in a given country. It is also worth noting that among immigrants, a large percentage are applying for asylum or refugee status, justifying their arrival in the host country with political factors such as persecution, fear for life and health or warfare. Not without significance, for the wave of migrants, is also the fact that Germany, as well as Great Britain and France, enjoy great popularity among immigrants. Such popularity is spread through social media, television or simply the word of mouth. These programs, presenting European countries as immigrants - friendly, - received immigrants in refugee camps, and even motivate them to enter the countries regardless of the personal cost. This draw has resulted in, hundreds of victims in the Mediterranean Sea, attempting to cross the ocean in unsafe crafts and usually resulting in losses of lives. The International Organization for Migration calls this sea "the deadliest frontier in the world," since more than 33,000 people have drowned in Mediterranean waters since 2000 .

Another factor that activates migration is the war with the so-called Islamic State and other terrorist organizations. As Świderski (2016) notes, it caused "the influx of hundreds of thousands of refugees to Europe to a large extent of Islamic religion. Terrorists say that among these people there are several thousand of their fighters, whose aim is to introduce permanent unrest in Europe. (...) Moreover, the world is probably also on the eve of a cultural war, which for many observers of social reality is inevitable. This claim is prompted by the behavior of existing Islamic minorities in Europe, which do not want to assimilate, do not recognize European values and do not intend to comply with the existing law. The dissatisfaction of European communities is growing. They express their dislike of refugees and the way the political elites conduct their policy towards them more and more clearly. Various restrictions on civil liberties are being introduced more and more often to increase security".

When it comes to Poland, it also has to deal with a significant increase in the number of foreigners in it. Since 2014, Poland has been constantly recording an increase in the number of foreigners applying for residence permits in it. Temporary migrations prevail - 88\% of applications in 2017 concerned temporary residence permits (up to 3 years), $10 \%$ permanent residence, and $2 \%$ long-term resident's EU stay. Almost $65 \%$ of all applications were submitted by persons aged 20-39. Citizens of Ukraine who wanted to live in Poland, submitted 125,000 applications in 2017 with an increase of $30 \%$ compared to 2016 . Belarusians $(9,500)$, Hindu $(8,000)$, Vietnamese $(6,400)$ and Chinese $(6,000)$ also applied for residence permits. As early as in 2005, 858 people had the right of permanent residence in Poland, and in 2014 it was already 18.9 thousand, of which most were Chinese, Vietnamese and Ukrainians (Office for Foreigners, 2018).

Polish migration issues are not only the challenges associated with immigration, but also the emigration of Poles abroad. After the country's accession to the European Union, most migration was on economic grounds, but the fact is that between 2010 and 2015, between 2 and 2.39 million people left Poland, of which the largest group went to the United Kingdom - 720 thousand, and to Germany - 655 thousand (Central Statistical Office, 2016). It is also worth adding that among this group, over $50 \%$ of people on the islands and almost $40 \%$ in Germany declared their will to stay permanently in these countries. This trend remains stable, which is confirmed by the data from the end of 2018, according to which around $2,455,000$ people stayed temporarily outside Poland. In Europe alone, there were about 2155 thousand people, most of them - about 2031 thousand. - stayed in 
the EU member states. Among the EU countries, the greatest number of Polish emigrants stayed in Germany (706 thousand), Great Britain (695 thousand), the Netherlands (123 thousand) and in Ireland (113 thousand) (Central Statistical Office, 2020).

Resulting problems have been felt in the economic dimension due to the shortage of workers, or in the social area, resulting from the increased number of divorces, leaving children without due care, the socalled Euro-orphanage, and retirement benefits. The discussed processes immigration and emigration also have a significant impact on the functioning of dispositional groups, because officers of these formations are most often the first to have direct contact with the incoming population who is attempting to enter the host country through legal or illegal means. Hence, the issues raised in advance with the migration movements can contribute to understanding the essence of the case and to developing mechanisms and solutions that will positively influence the alleviation of difficult migration processes that have been taking place in Europe for several years.

\section{Impact of migration on the operational efficiency of dispositional groups}

Considerations on the impact of migration on dispositional groups should begin with an analysis of the functioning of the environment of the groups themselves, especially in the context of problems that have been observed in uniformed services for some time. An issue worthy of mention first is personnel problems, which have been visible in many uniformed services for several years. An example would be the Polish Police, in which, due to the significant lack of officers, one might describe it as a personnel crisis. The head of Independent Self-Governing Trade Union of Policemen R. Jankowski states that "there are already nearly 6,000 vacancies, and fewer and fewer willing to join the police" (2019).

According to the data of the National Police Headquarters, 3.2 thousand officers left the forces in 2019, and 1.8 thousand were taken on. This depletion of numbers is reflected in the quality of "services" provided by policemen, manifested in the time of patrols undertaking interventions. So, this affects the local society which most needs support and help in maintaining security and public order. The low attractiveness of pay in the police, the hardships of service, and above all the outflow of young people at working age abroad - these are the main reasons for the staff deficit in this formation. And this has a direct negative impact on ensuring security and public order, already a formidable challenge. The influx of immigrants only compounded this challenge. An excellent native example is the area near Warsaw, where the center of wholesale trade of Asian goods is located. There are several thousand companies, gastronomic and service establishments, as well as financial institutions, and the area has developed its own security agency. The nature of this security results in_all services facing difficulties with entering, the country, from the police to the sanitary and tax and customs departments.

In some other European cities the challenges are even greater. An extremely worrying manifestation of this is the acts of terror committed in recent years, or the harassment of women on New Year's Eve in Cologne in 2015. It is also worth noting that the activity of mafia criminal groups increased and there was also an increase in common and criminal offences, which gives rise to very serious consequences for the safety of the inhabitants of the region. An example in this regard may be Germany, in which 181 thousand acts of violence were reported in 2014, and two years later their level increased to 193.5 thousand. As for the indicators for one of the German Lands - Lower Saxony, the increase in crime was even more visible. From the level of 17,500 crimes in 2014 to 19.2 thousand in the next two years, and most importantly, migrants account for 92 percent of them (Polityka, 2018). It should be noted that the number of crimes committed is not entirely accurate as many crimes were not reported to the police, especially in those districts where it is difficult or dangerous for 
government agencies to enter, a problem that appears to be more regularly reported.

The emergence of the so-called no go zone or no go area is a characteristic of Swedish cities, where walking in some parts of the city can threaten the life and health of not only citizens, but also uniformed services, especially the police. The term itself means areas where the level of violence and crime is so high that it prevents people from functioning normally and forces them to live in constant fear. No-go area can also mean an area that is controlled by a group of people who, by force and intimidation, prevent others (strangers) from crossing the border of "their" territory. At the end of 2014, the Swedish police published a report for the first time detailing areas that are problematic from the point of view of the work of uniformed services. At that time there were 55 such places on the Swedish map. However, in three years their number increased. In July 2017, the police published another document: "Utsatta områden - Social ordning, kriminell Konstrukcji och utmaningar för polisen" ("Sensitive places - social order, criminal structures and challenges for the police"), including a list of 61 problematic areas in Sweden, among which the largest concentration is located on the outskirts of the three largest cities: Stockholm, Malmö and Gothenburg. The police admit that they are powerless in the face of the situation, and one of the Swedish National Defense Academy's terrorist analysts M. Ranstorp said in his report: "In some areas, extremists have taken control. Basic standards of justice and social peace are at stake. The police are falling apart and it's getting worse. We're dealing with a disaster in Sweden" (TVP, 2019).

A further point relevant to the issue of staff deficit, is an issue the British police are facing. The issue is regarding the traditional clothing worn by Muslim women which covers the face, a traditional Muslim burqa. According to one West Midlands police commissioner, it is worth considering the service of burqa policewomen to increase the "ethnic diversity of police officers" (Rzeczpospolita, 2019). This is also associated with staffing problems, and such a solution might attract new recruits. However, this is contrary to the increasingly sharper trend visible in European countries, such as Denmark, France or Belgium, where it is forbidden to wear the burqas in public places, including the streets. In the Netherlands, however, women's rights to wear face veils have been restricted in places such as schools, hospitals, public transport, and government buildings. In 2014, the European Court of Human Rights ruled that such bans do not constitute a violation of religious freedoms.

Staffing difficulties are visible not only in the police, but also in the German armed forces. In 2011, in connection with the Bundeswehr reform, compulsory conscription was abolished, at the same time assuming an increase in its number to 200,000 professional soldiers. Unfortunately, the army appears to have lost its popularity as an employer, and currently, there is a shortage not only of the volunteers for professional services, but also of the technical staff (Military Magazine, 2019). This has resulted in German planners recruiting Poles, Italians and Romanians living in the Federal Republic between the ages of 18 and 40 . The choice of these nationalities is the result of a simple numerical factor, 255,000 Poles, 185 thousand Italians and 155,000 Romanian at conscript age living in Germany permanently. Altogether, they constitute about half of foreigners from European Union countries in the Federal Republic. If the willingness to take up service in the Bundeswehr structures was expressed by at least $10 \%$, this would result in 50,000 recruits (Military Magazine, 2019).

In addition, the option of recruiting EU citizens for the military service is also being considered, as it is done in other EU countries such as Belgium, Denmark, France, Spain, Luxembourg and the United Kingdom. What could the implications of this, for example, for the Polish armed forces be? Namely, the fact that the German employer will be more attractive than the Polish Ministry of National Defense, 
offering better wage conditions and services, and due to the close proximity it may be a significant incentive for Polish citizens to join the German army. Of course, there are ethical, loyal and patriotic problems, and there are some with the opinion that such personnel policy will lead to the appearance of an army of mercenaries, not soldiers ready to fight for their homeland.

Another example of a different approach to immigrants can be seen within the German Fire Brigade Association (Deutscher Feuerwehr Verband). They assumed that the fire brigade was perceived as a traditional organization associated with the uniform, command structures, hierarchies, service levels and regulations. Therefore, they considered it to be an important challenge to be open to groups previously under-represented in their ranks, positively recruiting people with a migration background. The organization formulated its mission as follows: enabling migrants to participate in fire brigades and to increase the intercultural competence of professional firefighters and volunteers (Feuerwehrband, 2019). The justification for such actions is the assumption that "people with a migration background are needed because: 1 . they are part of the society and can enrich fire departments culturally, linguistically, tactically-operationally as well as in an HR way; 2. their experience makes it possible to help with language barriers and possible cultural and behavioral differences; 3 . they broaden the horizons of existing guard members; 4. they have a positive effect on operational efficiency. Fire brigades perceive themselves as a reflection of the image of society and thus, want to include all sections of the population in their ranks, and their special experience is needed in fire departments". Thus, in the future the fire department will reflect a broad crosssection of society, enriched by the special qualifications and experience of people with a migration background.

The use of immigrants in the ranks of the fire brigade in order to overcome cultural and language barriers, among others, is another challenge for officers of dispositional groups. Entering the socio-cultural area of contemporary migrations, it is worth noting that this is a complex issue, conditioned by many factors.

First, we are dealing with a completely different family model in Muslim communities. Most often they are families with many children, patriarchal, with a privileged position of a man and a much weaker role of a woman, who often, due to lack of education and language skills have difficulties interacting with the external environment, and in extreme cases, may become a victim of domestic violence. Standard behaviors in female-male relationships developed in European civilization are completely unsuitable for Muslim populations, and have, on occasion, been a reason for misunderstandings and violence. In Islam, the prohibition on marriage between a Muslim and a nonMuslim is widely known, and in some cases, this has resulted in severe physical punishment towards the women. Therefore, dispositional groups that are strongly dominated by men, even if they are tasked with saving lives or nurturing health should be particularly careful and thoughtful, so as not to violate the cultural and moral principles in force in the community.

Secondly, the language barrier, the challenge of this problem can be seen in the situation in Sicily, where there were people in the refugee camp who taught English in their own countries. Due to the inability to communicate with city guards who spoke only Italian, immigrant teachers came up with the initiative to teach Italians English, in return for learning Italian. It transpired that knowledge of English is of enormous benefit in the city guard on the island, whose representatives have daily contact with immigrants and refugees, who often know only this foreign language (Interia, 2019).

An issue that is worth paying a particular attention to is the availability of uniformed formations to detect and counteract terrorist attacks. Based on the data 
presented by Europol Executive Director Catherine De Bolle in the 'Report on the situation and trends in the field of terrorism' summarizing 2018 before the Committee on Civil Liberties, Justice and Home Affairs (LIBE) (European Parliament 2019), it can be concluded that the number of victims of religious / jihadist terrorism in the EU fell. In 2018, 13 people were killed in the terrorist attacks in Trèbes, Paris, Liege and Strasbourg, compared to 62 people in 2017. However, it should be emphasized that the number of thwarted attacks has increased, which indicates that the threat to the internal security is still high. In 2018, one jihadist attack failed in Spain, and 16 incidents were reported as thwarted jihadist terrorist conspiracies, compared with 12 and 11 cases respectively in 2017. Jihadist attacks that were carried out and unsuccessful mostly took place using knives and firearms and were aimed mainly at civilians. All planned attacks using explosives were thwarted and most of the perpetrators acted or planned to act alone. As for the number of detained persons, a total of 511 suspects were arrested in 2018, mainly in France, Great Britain and Belgium, while in 2017 - 705. What caused a decrease in the number of terrorist attacks or their attempts in Europe? According to Catherine De Bolle, "efforts by law enforcement, security services, public authorities, private companies and civil society organizations to counter terrorism have significantly contributed to reducing violence in Europe".

When comparing the experience of Polish and other European countries in this area, Poland is not a priority target for extremist organizations; however, due to its participation in the anti-terrorist campaign or NATO and EU operations, it must take into account the possibility of such activities on its territory. A confirmation of this thesis may be one of the last operations of the Internal Security Agency, as a result of which, in December 2019, a Ukrainian citizen was detained. He was suspected of preparing to carry out an explosion of explosives using a trap car under one of the shopping malls, which could have seriously threatened the life, health and property of citizens.

\section{Conclusion}

Creating and maintaining an acceptable level of security in the micro-, mezzo- and macro-social dimension has become a fundamental challenge today. The etymology of the word 'security' in many languages underlines the primordial sense of danger in relation to the sense of security certainty. An example would be the Polish language, in which the old Polish word "without care" meant to remain without sufficient and adequate protection. Hence, since the appearance of man on Earth, he has taken actions to ensure the protection and defense of life and health, and over the time, of property and the environment against threats typical of a given age.

The capacity of the word security, both in terms of subject (personal, local, national, international) and object (political, cultural, economic, social, military, other) means that in a democratic state, virtually every public institution or social entity has statutory provisioned specific tasks to be performed as part of creating security in many dimensions. These institutions are nowadays referred to as dispositional groups, and the attributes assigned to them, such as professionalism, rule of law, professional and social competences, and readiness to act, particularly predispose them to counteract threats, among which the migration crisis is the most important characteristic of the 21st century.

Due to the universality of this phenomenon, which has affected all European countries, on the basis of the comparative studies conducted, it can be concluded that the problems faced by Western European countries can be extended to all countries of Central and Eastern Europe. Migration movements are a natural and irreversible process taking place in all types of society, bringing with them both opportunities and threats. Among the greatest advantages of migration, it is worth mentioning the economic, cultural, economic and demographic aspects, as well as social progress and the acquisition of labor, 
without which, the economy of many countries would not function at a high level of development. The threats that arise in connection with migration, especially uncontrolled immigration, include all those factors that affect the sense of multidimensional security. This applies in particular to public safety and order, social and health security, cultural security and national identity, as well as violations of human rights and freedoms resulting from human trafficking or forced labor. Hence, these areas should be under special control and protection of the state and disposable groups acting on its behalf. Therefore, the officers working in them should have special competences to perform tasks that differ from the schemes used so far.

Currently, in the functioning of the disposition groups, problems of a personnel and image-related nature can be noticed, which creates the necessity to adopt a long-term strategy enabling service in these formations of foreigners of different religions and customs. Intercultural education and language courses are essential, especially among officers at the operational level, where there is real contact between the migrant and the representative of the uniformed formation. This will make it possible to overcome language and cultural barriers and prepare the personnel of uniformed formations to perform statutory tasks.

The presented analysis of the experiences of European countries in solving problems in the officer-immigrant relationship is of a utilitarian nature, especially from the perspective of Central and Eastern European countries. They are the border states of the European Union, which in the first place take on the responsibility of solving migration problems. It is also them that, despite the fact that, so far, they are treated as transit countries, more and more countries, like Poland, - are becoming places of permanent emigration, therefore the migration policy should be adapted to new challenges.

\section{References}

- $\quad$ Balicki, J. (2012) Imigranci i uchodźcy w Unii Europejskiej, humanizacja polityki imigracyjnej i azylowej, UKSW Press, Warsaw.

- $\quad$ Balicki, J. and Necel, W. (ed.) (2017) Kryzys migracyjny w Europie. Wyzwania etyczne, społecznokulturowe i etniczne, UKSW Press, Warsaw.

- Bazan, J. L. (2017) A retugee crisis in Europe? Questioning perception in the current migration debate, Kryzys migracyjny w Europie. Wyzwania etyczne, społeczno-kulturowe i etniczne, Balicki J. and Necel W. (ed.), UKSW Press, Warsaw.

- $\quad$ Bogdalski, P. Bukowiecka, D. Częścik, R. and Zdrodowski, R. (ed.) (2014) Grupy dyspozycyjne społeczeństwa w świetle potrzeb bezpieczeństwa państwa, WSPol. Press, Szczytno.

- Bsoul-Kopowska, M., (2017), 'Zarządzanie rozwojem pracownika w grupach dyspozycyjnych', Zeszyty Naukowe Politechniki CzęstochowskiejZarządzanie $\mathrm{Nr} 25$ t. 1. [Online], [Retrieved August 21, 2019], http://www.zim.pcz.pl/znwz

- Castles, S. and Miller, M. J. (2011) Migracje we współczesnym świecie, PWN Press, Warsaw.

- Central Statistic Office, 2018. [Online], [Retrieved April 16, 2018], www.stat.gov.pl/obszarytematyczne/ludnosc/migracjezagraniczne-ludnosci/informacja-orozmiarach-i-kierunkach-czasowejemigracji-z-polski-w-latach-20042018,2,12.html

- COBOS, (2013), 'Prestiż zawodów', BS/164/2013 November 2013. [Online], [Retrieved August 22, 2019], https://www.cbos.pl/SPISKOM.POL/2 013/K_164_13.PDF

- European Parliament, 2019, 'Terroryzm w UE: ataki, ofiary śmiertelne i zatrzymania'. [Online], [Retrieved December 12, 2019], https://www.europarl.europa.eu/new s/pl/headlines/security/20180703ST 007125/terroryzm-w-ue-ataki-ofiarysmiertelne-i-zatrzymania

- European Parliament, 2019. [Online], [Retrieved January 23, 2020], 
www.europarl.europa.eu/news/pl/hea dlines/society/20170629STO7,

- Feuerwehrband, 2019, 'DFV-Beirat berät $\mathrm{zu}$ neuen Ansätzen für Integration'. [Online], [Retrieved August 23, 2019], http://www.feuerwehrverband.de/file admin/Inhalt/SCHWERPUNKTE/Integ ration

- Independent Self-Goveming Trade Union of Policemen, 2019. [Online], [Retrieved August 23, 2019], https://nszzp.pl/aktualnosci/policjigrozi-kadrowy-kryzys-nowegoministra-czekaja-stare-problemy/

- Interia, 2019. [Online], [Retrieved August 23, 2019], https://fakty.interia.pl/raporty/raport -imigranci-z-afryki/informacje/newsmigranci-nauczaja-straznikow-jezykaangielskiego,nId,2205673

www.poland.iom.int

- Janicka, A. (2018) Skutki procesów migracyjnych, 25 wykładów o migracjach, Lesińska M. and Okólski M. (ed.), Scholar Press, Warsaw.

- Lipińska-Rzeszutek, M. and Łapińska, A. (2016) Policja wobec zagrożeń bezpieczeństwa publicznego na tle kulturowym, Zadania jednostek administracyjnych samorządu terytorialnego $\mathrm{z}$ wykorzystaniem potencjału grup dyspozycyjnych w przezwyciężaniu zagrożeń bezpieczeństwa publicznego, Maciejewski J., Stochmal M., and Sokołowska A., (ed.) UWr. Press, Wrocław.

- Maciejewski, J. (2012) Grupy dyspozycyjne. Analiza socjologiczna, Difin Press, Warsaw.

- Matis, J. (2016) Migracia - vyznamny faktor europejskiej integraciepohotovostnych skupin, Zadania jednostek administracyjnych samorządu terytorialnego $\mathrm{z}$ wykorzystaniem potencjału grup dyspozycyjnych $\mathrm{w}$ przezwyciężaniu zagrożeń bezpieczeństwa publicznego, Maciejewski J., Stochmal M., and Sokołowska A., (ed.) UWr. Press, Wrocław.

- Military Magazine, 2019. [Online], [Retrieved August 23, 2019], https://www.milmag.pl/news/view?n ews_id $=1783 \& q$

- Morawski, Z. (2005) Prawne determinanty pozycji, roli i statusu warstw dyspozycyjnych społeczeństwa Polski na przykładzie trzech organizacji formalnych, UWr. Press, Wrocław

- Office for Foreigners, 2018. [Online], [Retrieved May 7, 2018], www.udsc.gov.pl

- Polityka, 2018, 'Przestępczość imigrantów w Niemczech: fakty i mity'. [Online], www.polityka.pl

- Przytuła, S. (ed.) (2017) Migracje międzynarodowe i ekspatriacja. Perspektywa indywidualna, organizacyjna, społeczno-kulturowa, Difin Press, Warsaw.

- Robertson, D. (2009) Słownik polityki, Sic! Press, Warsaw.

- Rzeczpospolita, 2019. [Online], [Retrieved October 16, 2019], https://www.rp.pl/Spoleczenstwo/16 0909013-Brytyjski-komisarz-policjiPolicjantki-moglyby-nosic-burki.html

- Świderski, K. (2016) Synergia samorządu terytorialnego oraz grup dyspozycyjnych

w przezwyciężaniu zagrożeń bezpieczeństwa publicznego, Zadania jednostek administracyjnych samorządu terytorialnego $\mathrm{z}$ wykorzystaniem potencjału grup dyspozycyjnych w przezwyciężaniu zagrożeń bezpieczeństwa publicznego, Maciejewski J., Stochmal M., and Sokołowska A., (ed.) UWr. Press, Wrocław.

- TVP, 2019. [Online], [Retrieved March 15 , 2019], https://www.tvp.info/42918502/60stref-zagrozonych-przestepczoscia-wszwecji-od-lat-sytuacja-sie-niepoprawia

- TVN, 2018, 'Raj nazywa się Almaniya”. Co przyciąga imigrantów do Niemiec'. [Online], [Retrieved September 16, 2018], www.tvn24.pl/

- World Migration Report, 2020. [Online], [Retrieved September 6, 2020],

https://publications.iom.int/books/wo rld-migration-report-2020 
- Zagórski, Z. (2000) Grupy dyspozycyjno-mundurowe w toku transformacji, „Wojsko i inne grupy dyspozycyjne w perspektywie socjologicznej", Leczykiewicz T. and Zagórski Z. (ed.) Zeszyty Naukowe Wyższej Szkoły Oficerskiej im. T. Kościuszki, 4: 56-78
- Zalewski, S. (2014) Grupy dyspozycyjne w społeczeństwie obywatelskim, Grupy dyspozycyjne społeczeństwa $\mathrm{w}$ świetle potrzeb bezpieczeństwa państwa, Bogdalski, P. Bukowiecka, D. Częścik, R. and Zdrodowski, R. (ed.) WSPol. Press, Szczytno 